\title{
Kerentanan Banjir Berdasarkan Tingkat Urban Sprawl
}

\author{
*Linda Dwi Rohmadiani, Dio Perdana Erditya Subekti \\ Program Studi Perencanaan Wilayah dan Kota, Universitas PGRI Adi Buana Surabaya \\ *linda@unipasby.ac.id
}

INFO ARTIKEL
Riwayat Artikel:
Diterima: 19-1 1-2019
Disetujui: 09-05-2020

\section{Kata Kunci:}

Rentan Banjir

Urban Sprawl

Periphery Kota Surabaya

\begin{abstract}
ABSTRAK
Abstrak: Daerah rentan banjir adalah daerah yang berpotensi tinggi untuk terlanda banjir. Tingkat kerentanan banjir dapat ditentukan berdasarkan curah hujan, kelerengan lahan, struktur tanah dan penggunaan atau tutupan lahan. Wilayah Gresik Selatan merupakan daerah periphery Kota Surabaya tertutama untuk bidang perumahan. Tujuan penelitian ini adalah menganalisis tingkat kerentanan banjir berdasarkan tingkat urban sprawl dengan menggunakan metode skoring, overlay dan crastabulation. Metode pengumpulan data dilakukan melalui survei instansi. Hasil penelitian menunjukkan bahwa wilayah Gresik Selatan $56,6 \%$ sangat rentan terhadap banjir yang terdiri atas 3,3\% urban spraw/ rendah, 36,1\% urban sprawl sedang dan 17,2\% urban sprawl tinggi. Urban sprawl di wilayah Gresik Selatan tidak bisa dicegah tetapi pemerintah perlu antisipasi dampaknya terhadap lingkungan, lalu lintas, sosial dan ekonomi.
\end{abstract}

\begin{abstract}
Flood prone areas are areas with high potential for flooding. Flood susceptibility can be determined based on rainfall, slope, soil structure and land use or cover. South Gresik Region is the periphery of Surabaya City especially in the housing sector. The purpose of this study is to analyze the level of flood vulnerability based on the level of urban sprawl by using scoring, overlay and crastabulation methods. The method of data collection is done through agency surveys. The results showed that $56.6 \%$ of South Gresik area was very vulnerable to flooding which consisted of 3.3\% low urban sprawl, 36.1\% medium urban sprawl and $17.2 \%$ high urban sprawl. Urban sprawl in the South Gresik region cannot be prevented but the government needs to anticipate its impact on the environment, traffic, social and economy.
\end{abstract}

\section{A. LATAR BELAKANG}

Wilayah Pembangunan Gresik Selatan menurut Peraturan Daerah Kabupaten Gresik No 8 Tahun 2011 tentang Rencana Tata Ruang Wilayah Kabupaten Gresik Tahun 2010-2030 meliputi Kecamatan Driyorejo, Kedamean, Menganti dan Wringinanom dengan arahan peruntukannya sebagai kawasan permukiman atau penyangga Kota Surabaya di bidang permukiman. Wilayah ini terbagi menjadi 69 desa dengan rincian Kecamatan Wringinanom terdapat 16 desa, Kecamatan Driyorejo terdapat 16 desa, Kecamatan Menganti terdapat 22 desa dan Kecamatan Kedamean terdapat 15 desa. Ketinggian lahan wilayah Pembangunan Gresik selatan $47 \%$ dengan ketinggian 10-20 mdpl dan 53\% dengan ketinggian 0-10 mdpl, sedangkan dari kelerengan lahan $84 \%$ dengan kemiringan 0-2\% dan 16\% dengan kelerengan $3-5 \%$ artinya termasuk dataran rendah. Pola penggunaan lahan wilayah pada Tahun 2017 menurut BPS didominasi oleh lahan pertanian sebanyak $76 \%$ dan $24 \%$ merupakan lahan terbangun atau non pertanian. Kepadatan penduduk Tahun 2017 mencapai 1 jiwa per Ha atau termasuk kategori kepadatan penduduk rendah.
Hasil penelitian Tahun 2017 menunjukkan bahwa pada Kecamatan Menganti berkembang kurang lebih 21 perumahan developer. Penelitian Rohmadiani \& Ramayadnya (2016) dan Rohmadiani \& Dede (2017) menyimpulkan bahwa interaksi kewilayahan yang dilakukan salah satu wilayah Pembangunan Gresik Selatan (Kecamatan Driyorejo) cenderung kearah Kabupaten Sidoarjo dan Kota Surabaya, hal ini disebabkan oleh faktor jarak tempuh. Rohmadiani, dkk (2019) menunjukkan bahwa perkembangan pada ke 4 kecamatan tersebut disebabkan adanya aktivitas perembetan kota Kota Metropolitan Surabaya. Kecamatan Driyorejo merupakan wilayah dengan presentase urban sprawl tinggi terbanyak yaitu $69 \%$. Desiyana (2017) dalam penelitiannya menyatakan bahwa beberapa fenomena negatif yang diakibatkan dari aktivitas urban sprawl kota metropolitan seperti kemacetan, banjir, polusi udara dan pencemaran air. Berdasarkan hasil kajian literalur tersebut maka diperlukan penelitian lebih lanjut mengenai kerentanan banjir pada wilayah yang terindikasi tingkat urban sprawl tinggi di Wilayah Pembangunan Gresik Selatan. Desa Kesamben Wetan salah satu wilayah Kecamatan Driyorejo yang berada di tepi Kali Avur Tahun 2019 
mengalami kebanjiran sebanyak 9 kali, penyebab banjir karena pendakalan sungai (www.surya.co.id)

\section{B. METODE PENELITIAN}

Pendekatan penelitian yang digunakan dalam penelitian ini adalah deksriptif kuantitatif dengan teknik analisis skoring dan overlay union.

Perhitungan tingkat rentan banjir menggunakan metoda skoring tersebut adalah berdasarkan formula berikut ini: (Nanik dkk, 2008 dalam Wismarini dkk, 2015)

$$
\begin{aligned}
& \text { Rentan banjir }=\mathbf{N V}(\mathbf{L u})+\mathbf{N V}(\mathbf{T p}) \\
& \qquad+\mathbf{N V}(\mathbf{S o})+\mathbf{N V}(\mathbf{R o})
\end{aligned}
$$

\begin{tabular}{|c|c|c|c|}
\hline No & $\begin{array}{c}\text { Variabel } \\
\text { Indikator }\end{array}$ & Kelas Variabel & Skor \\
\hline \multirow[t]{4}{*}{1} & Intensitas & Rendah (500-1000 $\left.\mathrm{mm}^{3}\right)$ & 1 \\
\hline & curah hujan & $\begin{array}{l}\text { Sedang }(1000-1500 \\
\left.\mathrm{mm}^{3}\right)\end{array}$ & 2 \\
\hline & & Tinggi (1500-2000 $\left.\mathrm{mm}^{3}\right)$ & 3 \\
\hline & & $\begin{array}{l}\text { Sangat Tinggi }(>2000 \\
\left.\mathrm{mm}^{3}\right)\end{array}$ & 4 \\
\hline \multirow[t]{4}{*}{2} & Penggunaan & Rawa/ danau/tambak & 1 \\
\hline & lahan & $\begin{array}{l}\text { Semak belukar/ padang } \\
\text { rumput }\end{array}$ & 2 \\
\hline & & Persawahan/ pertanian & 3 \\
\hline & & $\begin{array}{l}\text { Permukiman/ industri/ } \\
\text { perkantoran }\end{array}$ & 4 \\
\hline \multirow[t]{4}{*}{3} & $\begin{array}{l}\text { Struktur tanah } \\
\text { (geologi) }\end{array}$ & $\begin{array}{l}\text { Latosol coklat tua } \\
\text { kemerahan }\end{array}$ & 1 \\
\hline & & Asosiasi aluvial kelabu & 2 \\
\hline & & Grumosol & 3 \\
\hline & & Aluvial & 4 \\
\hline \multirow[t]{4}{*}{4} & Kemiringan & Sangat tinggi (> 25\%) & 1 \\
\hline & lereng & Tinggi (15-25\%) & 2 \\
\hline & & Sedang (2-15\%) & 3 \\
\hline & & Rendah ( $0-2 \%)$ & 4 \\
\hline
\end{tabular}

\begin{tabular}{|c|c|c|c|}
\hline No & $\begin{array}{c}\text { Kelas } \\
\text { Kerentanan } \\
\end{array}$ & Klasifikasi & Keterengan \\
\hline 1 & Sangat rentan & $>13$ & $\begin{array}{l}\text { Bencana banjir } \\
\text { yang berdampak } \\
\text { besar pada } \\
\text { kehidupan } \\
\text { masyarakat }\end{array}$ \\
\hline 2 & Rentan & $10-12$ & $\begin{array}{l}\text { Bencana banjir } \\
\text { yang berdampak } \\
\text { cukup besar pada } \\
\text { kehidupan } \\
\text { masyarakat }\end{array}$ \\
\hline 3 & $\begin{array}{l}\text { Kurang } \\
\text { rentan }\end{array}$ & $7-9$ & $\begin{array}{l}\text { Bencana banjir } \\
\text { yang tidak } \\
\text { berdampak pada }\end{array}$ \\
\hline
\end{tabular}

Tabel 1

Skor Parameter Indikator Banjir

Sumber: Wismarini \& Sukur, 2015 diolah 2019

Tabel 2.

Tingkat Rentan Banjir

\begin{tabular}{cccl}
\hline No & $\begin{array}{c}\text { Kelas } \\
\text { Kerentanan }\end{array}$ & Klasifikasi & Keterengan \\
\hline \multirow{4}{*}{4} & Tidak rentan & $4-6$ & $\begin{array}{l}\text { kehidupan } \\
\text { masyarakat } \\
\end{array}$ \\
& & $\begin{array}{l}\text { Tidak pernah } \\
\text { mengalami banjir } \\
\text { juga tidak } \\
\text { mengakibatkan } \\
\text { bencana }\end{array}$ \\
& & & \\
& & & \\
\end{tabular}

Sumber: Wismarini \& Sukur, 2015 diolah 2019

Analisis kerentanan banjir selanjutnya menggunakan metode overlay union dengan langkah-langkah seperti pada Gambar 1.

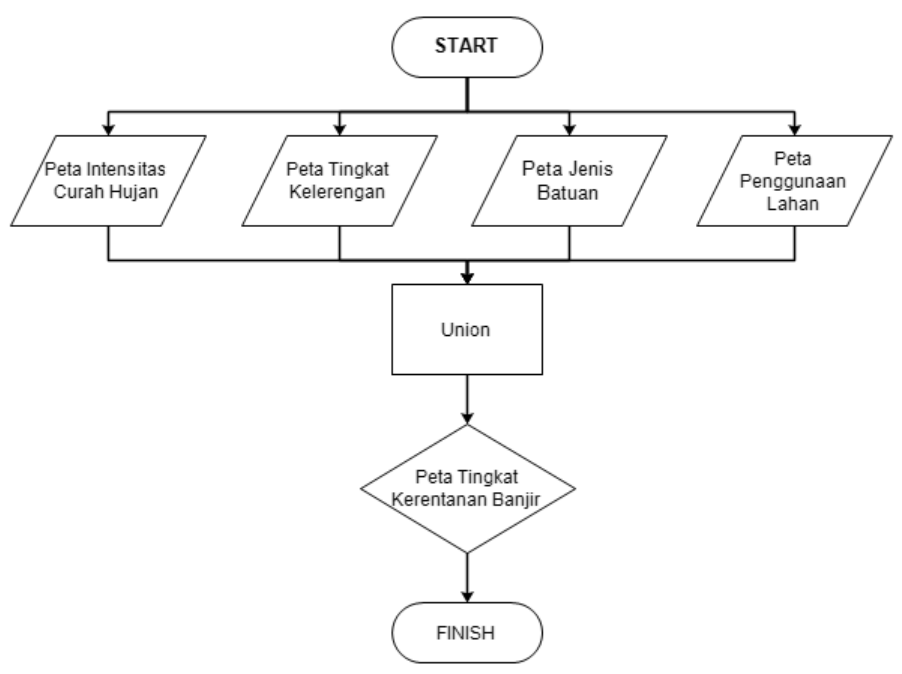

Gambar 1. Flowchart Analisis Overlay Union

Analisis crosstabulation adalah analisis korelasional yang digunakan utnuk melihat hubungan antar variabel. Variabel yang digunakan adalah tingkat kerentanan banjir dengan tingkat urban sprawl.

Ho $=$ Tidak ada hubungan antara tingkat urban sprawl dengan tingkat kerentanan banjir

$\mathrm{Ha}=$ Ada hubungan antara tingkat urban sprawl dengan tingkat kerentanan banjir

Pengambilan keputusan berdasarkan nilai signifikansi (Asymp. Sig) menurut Santoso (2014):

1. Jika nilai Asymp. Sig (2-sided) < 0,05 maka Ho ditolak dan Ha diterima

2. Jika nilai Asymp. Sig (2-sided) > 0,05 maka Ho diterima dan Ha ditolak

Data yang dibutuhkan dalam penelitian ini adalah data sekunder. Data sekunder diperoleh dari berbagai instansi seperti BAPPELITBANGDA, BIG serta instansi lain yang berkaitan dengan penelitian ini.

\section{HASIL DAN PEMBAHASAN}

\section{Kondisi Fisik Wilayah}

a. Curah Hujan

Curah hujan di Wilayah Gresik Selatan menurut data BPS pada Tahun 2018 seperti pada Gambar 2, mayoritas atau sebesar $58 \%$ berkisar antara 1.500 sampai dengan $2.000 \mathrm{~mm}^{3} /$ tahun dan $42 \%$ lebih dari $2.000 \mathrm{~mm}^{3} /$ tahun sehingga menyebabkan potensi banjir cukup besar 
terutama di Kecamatan Wringinanom dan Kecamatan Kedamean.

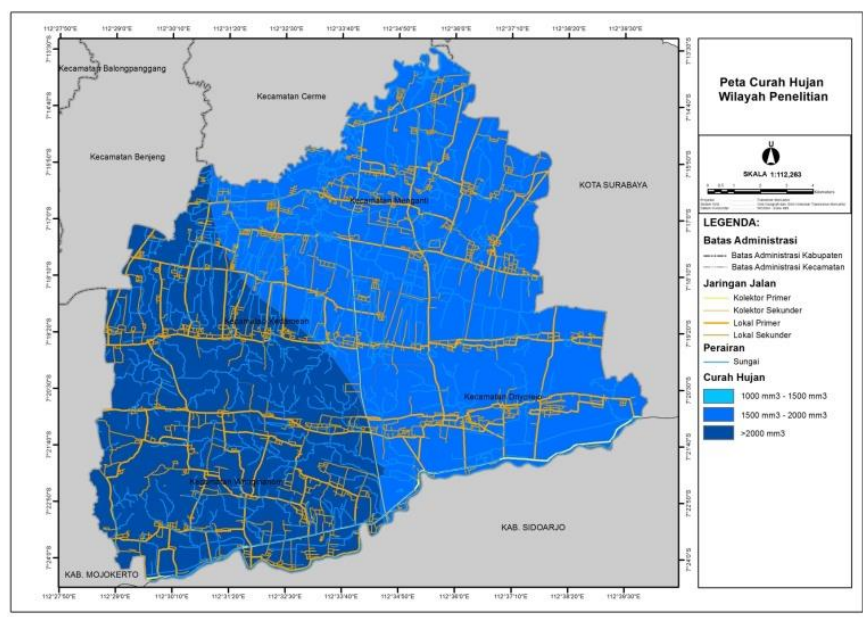

Gambar 2. Kondisi Curah Hujan

\section{b. Struktur Tanah}

Kondisi struktur di Wilayah Gresik Selatan menurut data BPS pada Tahun 2018 seperti pada Gambar 3, mayoritas (63\%) berjenis aluvial kelabu dan $37 \%$ berjenis grumosol kelabu tua. Tanah aluvial merupakan tanah endapan dibentuk dari umpur dan pasir halus yang mengalami erosi tanah. Banyak terdapat di dataran rendah, di sekitar muara sungai, rawa-rawa, lembahlembah maupun di kanan-kiri sungai besar. Jenis tanah ini baik dimanfaatkan untuk tanaman pangan musiman hingga tahunan. Jenis tanah grumosol teksturnya kering dan mudah pecah. Tanah ini tidak subur dan tidak cocok ditanami tanaman (https://ilmugeografi.com/ilmubumi/tanah/jenis-jenis-tanah). Berdasarkan data maka Kecamatan Wringinanom tidak cocok untuk pengembangan pertanian, sedangkan kecamatan lainnya cocok.

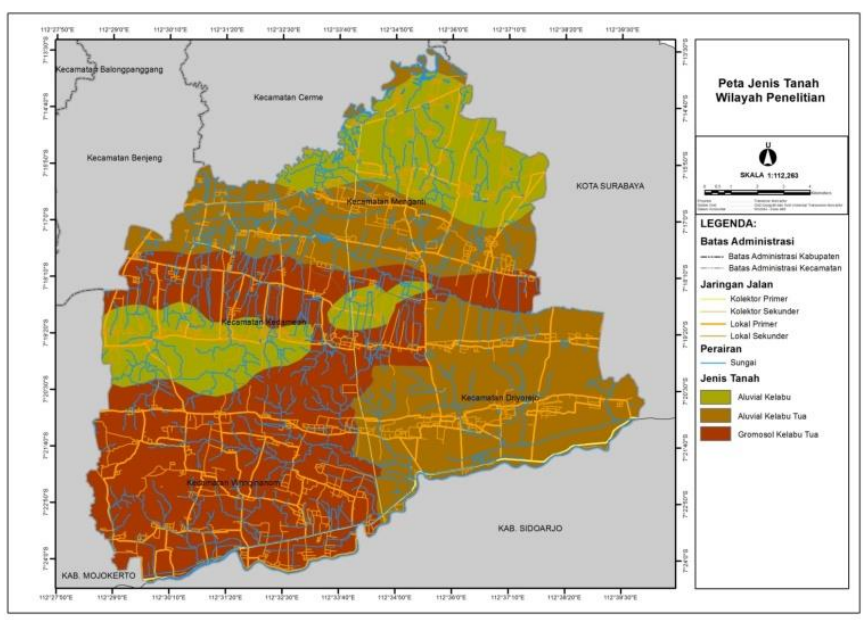

Gambar 3. Kondisi Struktur Tanah

\section{c. Tingkat Kelerengan}

Tingkat kelerengan di Wilayah Gresik Selatan menurut data BPS pada Tahun 2018 seperti pada Gambar 4, mayoritas $(73 \%)$ merupakan dataran rendah dengan tingkat kelerengan 0-2\% dan 27\% tingkat lerengannya 2$15 \%$. Kecamatan Menganti $100 \%$ wilayahnya berada di dataran rendah, sehingga memiliki potensi benjir yang terbesar. Kemiringan lahan berpengaruh besar terhadap nilai aliran permukaan dan erosi (Suryanto \& Wawan, 2017).

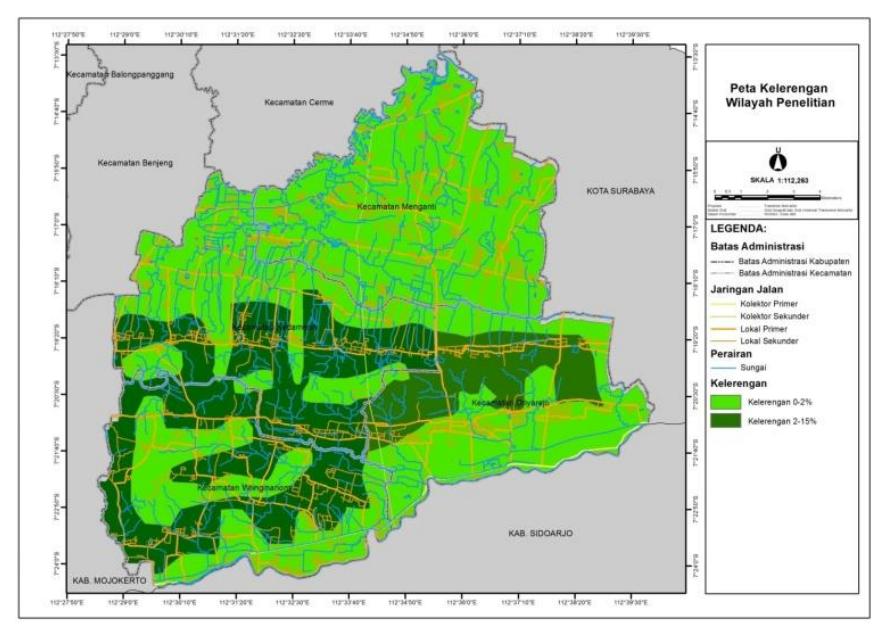

Gambar 4. Kondisi Tingkat Kelerangan

\section{d. Penggunaan Lahan}

Jenis penggunaan lahan di Wilayah Gresik Selatan menurut data BIG Tahun 2018 seperti pada Gambar 5, dominasi (85\%) berupa persawahan, 2 \% berupa rawa atau tambak atau semak belukar atau padang rumput dan 13\% merupakan lahan terbangun berupa permukiman, industri dan sarana perkotaan. Kondisi ini menunjukkan bahwa di wilayah Gresik Selatan masih bisa berkembang dalam jangka waktu panjang, dimana lahan terbangun sampai dengan Tahun 2018 sebesar 13\%. Peningkatan luasan lahan tertutup mengakibatkan penurunan kapasitas resapan sehingga menyebabkan banjir di Kecamatan Kartasura (Dahroni dkk, 2017) (Dahroni dkk, 2018).

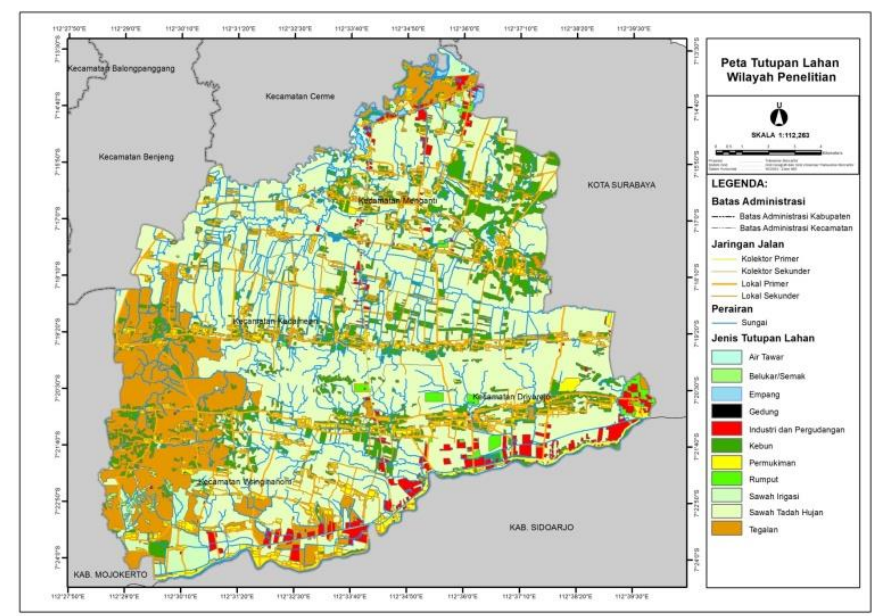

Gambar 5. Penggunaan Lahan

\section{Kerentanan Banjir}

Peta curah hujan, peta tingkat kelerengan, peta jenis tanah dan peta penggunaan lahan kemudian dianalisis spasial menggunakan metode skoring dan overlay union dengan ArcGIS sehingga diperoleh tingkat kerentanan banjir di masing-masing kecamatan pada Gambar 6. 


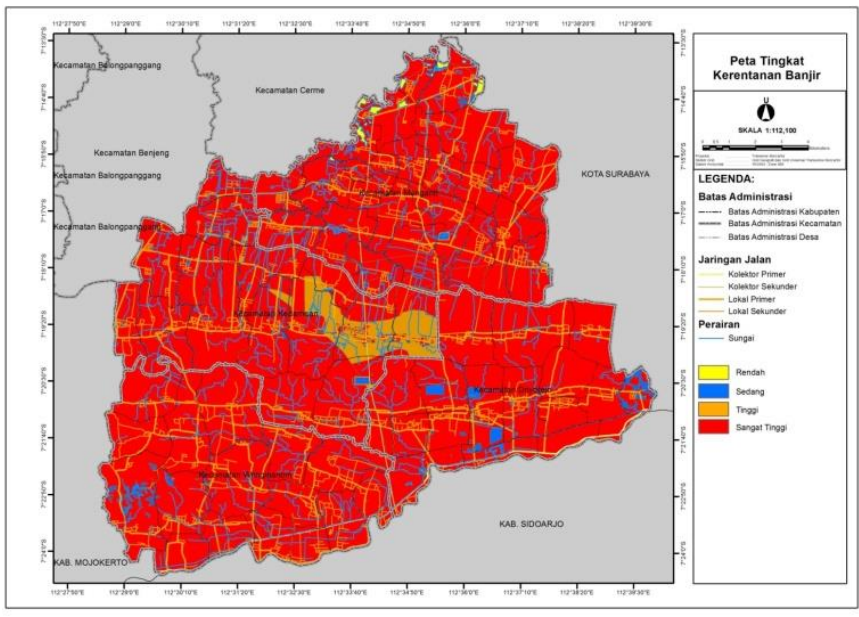

Gambar 6. Kerentanan Banjir

Gambar 6 menunjukkan bahwa tingkat kerentanan banjir sangat tinggi di wilayah Gresik Selatan pada Tahun 2018 hampir sebesar 96\% atau 24.144 ha. Kerentanan tinggi sebesar $3 \%$ atau $694 \mathrm{Ha}$, kerentanan sedang sebesar $1 \%$ atau 327 Ha dan kerentanan rendah sebesar 0,4\% atau 94 Ha. Kecamatan Wringinanom dan Kecamatan Driyorejo merupakan wilayah yang memiliki wilayah terbesar dengan kerentanan terhadap bajir sangat tinggi yaitu 99\% untuk Kecamatan Wringinanom dan 97\% untuk Kecamatan Driyorejo. Kecamatan Kedamean termasuk dalam wilayah yang relatif lebih aman terhadap banjir daripada 3 kecamatan lainnya, luas wilayah dengan kerentanan sangat tinggi terhadap banjir hanya sebesar $89 \%$. Kondisi ini menunjukkan bahwa prospek pengembangan wilayah kedepannya bisa lebih diarahkan ke wilayah tersebut.

Hasil penelitian Rohmadiani dkk (2019) menunjukkan bahwa 64\% (dari 69 desa) di wilayah penelitian tingkat urban sprawl sedang, namun pada wilayah Kecamatan Driyorejo 69\% atau 11 desa termasuk tingkat urban sprawl tinggi. Berdasarkan hasil penelitian tersebut maka dapat dikelompokkan menggunakan analisis crosstabulation bahwa tingkat urban sprawl rendah terdapat 1,6\% kerentanan sedang, 1,6 \% kerentanan tinggi dan 3,3\% kerentanan tinggi. Tingkat urban sprawl sedang terdapat 4,1\% tidak rentan banjir, 24,6\% sedang, 4,1\% rentan dan 36,1\% sangat rentan banjir. Tingkat urban sprawl tinggi terdapat $7,4 \%$ rentan sedang dan $17,2 \%$ sangat rentan terhadap banjir.

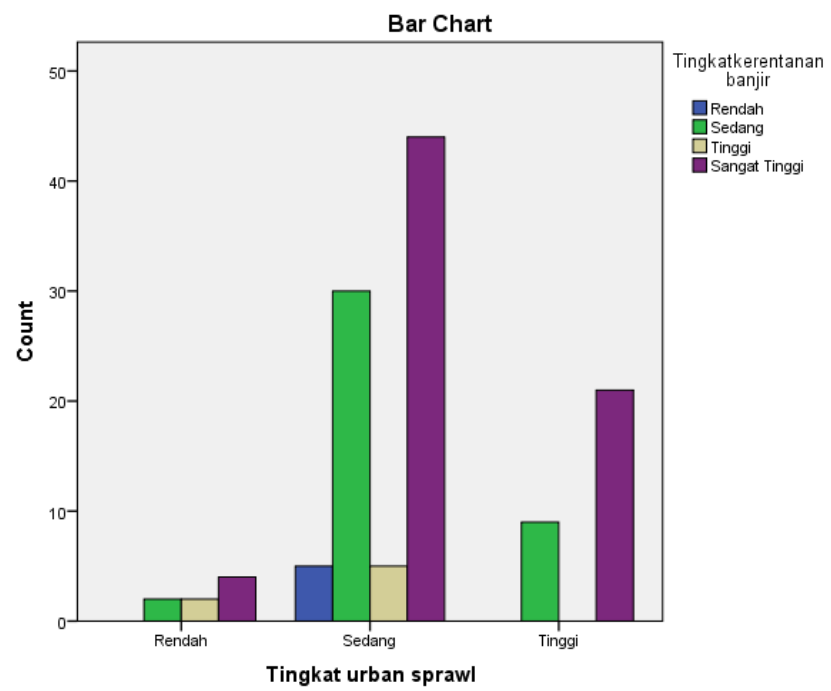

Gambar 7. Crostabulation Antara Tingkat Urban Sprawl dengan Kerentanan Banjir

Hubungan antara tingkat urban sprawl dengan tingkat kerentanan banjir berdasarkan analisis ChiSquare Test menunjukkan signifikansi $p$-value sebesar 0,093 (lebih besar dari 0,05), hal ini berarti tidak ada hubungan antara tingkat urban sprawl dengan tingkat kerentanan banjir di wilayah Gresik Selatan (Ho diterima Ha ditolak). Hasil analisis Chi-Square dijabarkan pada Tabel 3 .

Tabel 3

Hubungan Antara Tingkat Urban Sprawl dengan Tingkat Kerentanan Banjir Tahun 2018

\begin{tabular}{|l|r|r|r|}
\hline & Value & df & \multicolumn{1}{|c|}{$\begin{array}{c}\text { Asymptotic } \\
\text { Significance (2- } \\
\text { sided) }\end{array}$} \\
\hline Pearson Chi-Square & $10,845^{\mathrm{a}}$ & 6 &, 093 \\
\hline Likelihood Ratio & 11,629 & 6 &, 071 \\
\hline $\begin{array}{l}\text { Linear-by-Linear } \\
\text { Association }\end{array}$ & 1,274 & 1 &, 259 \\
\hline N of Valid Cases & 122 & & \\
\hline $\begin{array}{l}\text { a. } 8 \text { cells (66,7\%) have expected count less than 5. The minimum expected } \\
\text { count is ,33. }\end{array}$
\end{tabular}

\section{SIMPULAN DAN SARAN}

Kesimpulan yang dihasilkan dalam penelitian menunjukkan bahwa wilayah Gresik Selatan 56,6\% sangat rentan terhadap banjir yang terdiri atas $3,3 \%$ urban sprawl rendah, 36,1\% urban sprawl sedang dan $17,2 \%$ urban sprawl tinggi. 
Tim penulis mengucapkan terima kasih kepada LPPM Universitas PGRI Adi Buana Suarabaya yang telah mendanai penelitian ini.

\section{DAFTAR RUJUKAN}

[1] Anonim. 2011. Peraturan Daerah Kabupaten Gresik No 8 Tahun 2011 tentang Rencana Tata Ruang Wilayah Kabupaten Gresik Tahun 2010-2030. Gresik.

[2] Anonim. 2015. 8 Jenis Jenis Tanah di Indonesia: Manfaat, Persebaran, Gambarnya. https://ilmugeografi.com/ilmu-bumi/tanah/jenis-jenistanah.

[3] Sugiyono. 2019. Warga Driyorejo Sudah 9 Kali Kebanjiran dari Kali Avur, Dinas PUTR Gresik Sebut Bukan Kewenangannya. https://surabaya.tribunnews.com/2019/03/15/wargadriyorejo-sudah-9-kali-kebanjiran-dari-kali-avur-dinasputr-gresik-sebut-bukan-kewenangannya.

[4] Dahroni, Suharjo, Arozaq, M \& A, Baharudins Syaiful. 2017. Dinamika Urban Sprawl terhadap Kerentanan Bencana Banjir Pada Wilayah Kecamatan Kartasura. Prosiding Seminar Nasional Geografi UMS 2017. ISBN 978-602-361-137-9.

[5] Dahroni, Setiyadi, NA \& Arozaq, M. 2018. Perkembangan Dan Karakteristik Permukiman Urban Sprawl Kecamatan Kartasura, Sukoharjo Terhadap Kerentanan Banjir Sungai. Prosiding Seminar Nasional Geografi UMS IX 2018 ISBN: 978-602-361-137-9.

[6] Desiyana, I. 2017. Urban Sprawl dan dampaknya Pada Kualitas Lingkungan Studi Kasus di DKI Jakarta dan Depok, Jawa Barat. Jurnal Komunikasi Visual Vol X No. 2.

http://download.garuda.ristekdikti.go.id/article.php?art icle $=940863 \&$ val $=14591 \&$ title $=$ Urban\%20Sprawl\%20D an\%2oDampaknya\%2oPada\%2oKualitas\%2OLingkung an.

[7] Rohmadiani, LD dan Ramayadnya, AAGA. 2016. Identifikasi Keterkaitan Hinterland Dengan Pusat Kota. Proseding IPLBI 2016.

[8] Rohmadiani, LD dan Dede, FRB. 2017. Strategi Pengembangan Wilayah Hinterland Kabupaten Gresik. Jurnal Waktu Vol 15 No. 2.

[9] Rohmadiani, LD, Kunce, YA dan Rochmawanti, ID. 2019. Fenomena Urban Sprawl Wilayah Pembangunan Gresik Selatan. Jurnal Ikatan Peneliti Lingkungan Binaan.

[10]Santoso, S. 2014. Panduan Lengkap SPSS Versi 20. Jakarta: Gramedia.

[11] Suryanto \& Wawan. 2017. Pengaruh Kemiringan Lahan dan Mucuna Baracteata Terhadap Aliran Permukaan Dan Erosi Di PT. Perkebunan Nusantara V Kebun Lubuk Dalam. JOM FAPERTA Vol. 4 No. 1. https://media.neliti.com/media/publications/198712pengaruh-kemiringan-lahan-dan-mucuna-bra.pdf

[12]Wismarini, TD \& Sukur, M. 2015. Penentuan Tingkat Kerentanan Banjir Secara Geospasial. Jurnal Teknologi Informasi DINAMIK Vol. 20 No. 1 Januari 2015. 